\title{
Squamous Cell Carcinoma Metastatic in the Neck with Occult Primary
}

National Cancer Institute

\section{Source}

National Cancer Institute. Squamous Cell Carcinoma Metastatic in the Neck with Occult

Primary. NCI Thesaurus. Code C7713.

A squamous cell carcinoma that has metastasized to the neck region from an unknown primary anatomic site. 